\title{
第59回日本小児保健協会学術集会学会報告
}

\section{The 59th Annual Meeting of the Japanese Society of Child Health}

\section{会頭 小 田慈（岡山大学病院 小览血液腫掦科, 岡山大学大学院保健学研究科)}

Megumi Oda (Department of Pediatric Hematology and Oncology, Okayama University Hospital, Graduate School of Health Sciences, Okayama University)

第59回日本小児保健協会学術集会：メインテーマ 「愛しい子どもたちに〜今，私たちにできること」が， 平成 24 年 9 月 27 日（木） 29日（土）の 3 日間, 岡山 コンベンションセンターにおいて開催され, 学術集会 会頭を務めましたので，報告させていただきます。

本学術集会は会員数4,700名を擁する公益社団法人 日本小児保健協会が開催する年次学術集会で, 毎年春 に開催される日本小児科学会学術集会と並び, 我が国 の小児医療・保健・福祉に関する総合的かつ学術的な 大きな 2 つイベントの 1 つです。岡山で開催されま すのは, 昭和 42 年, 故浜本英次岡山大学名誉教授が第 14回学術集会の会頭を務められて以来，45年ぶりのこ とでした。

我が国は近年, 少子高齢化が進み, 社会情勢や人々 の生活様式も大きく変わり, 小児の医療, 保健, 福祉 そして教育のあり方にも大きな変革が望まれています。

移植医療, 再生医療などの先進医療の進歩などに伴 うチーム医療の重要性の認識とコンセンサスの形成, 卒後臨床研修制度の導入などに伴う地域における小児 科医の不足や偏在, そして小児医療施設の集約化と均 てん化, 時間外診療を含む小児救急の問題, 慢性疾患 や成長・発達障がいをかかえた子どもたちや，ご家族 の支援等々, 様々な問題が小児医療の現場に突きつけ られています。ささらに育児・養育過誤や児童虐待, 非 行の若年化, 引きこもりや通学困難, 地域・家庭にお ける子育てのあり方, 子どもにやさしい環境整備, 感 染症対策・ワクチン等による疾病予防など, 子どもた ちの, より良い成育環境作りの為の医療, 保健, 福祉 や教育の連携の必要性と重要性はかつてないほど強く 認識されています。従って, 小児を取り巻く生活環境 に係わるすべての職種の方々が職種の枠を超えて協力

平成 25 年 1 月受理

厂700-8558 岡山市北区鹿田町 2-5-1

電話：086-235-6901 FAX：086-235-6901

E-mail :megoda@md.okayama-u.ac.jp
して新しい知識の習得，そして技術の研鑽を㤐ること は許されません。

このような社会的状況・要請を背景に, 本学術集会 におきましては様々な方面からの招聘講演, 基調講演, 特別講演, 教育講演や一般講演, シンポジウム, 各種 セミナーなどを企画しました。

学術集会初日には, 小坚救急電話相談スキルアップ 研修会, DENVER II講習会に加え岡山県, 岡山県小览 保健協会との共催で，市民公開講座「虐待の連鎖を断 ち切る支援とは一親子と向き合う我々に, 求められて いること，できること一」を開催しました．300名余 の参加者があり，4名のパネリストによる講演のあと 熱心な質疑応答が続きました。

学術集会 $2 \sim 3$ 日目には各講演, シンポジウム, 一 般演題発表が行われました。 30 年以上にわたりユニセ フなどで国際公務員として活躍中の浦元義照氏による 招請講演「開発・紛争と平和構築 $\sim$ 国際公務員として 34年間の経験から伝えたいこと」では, American Field

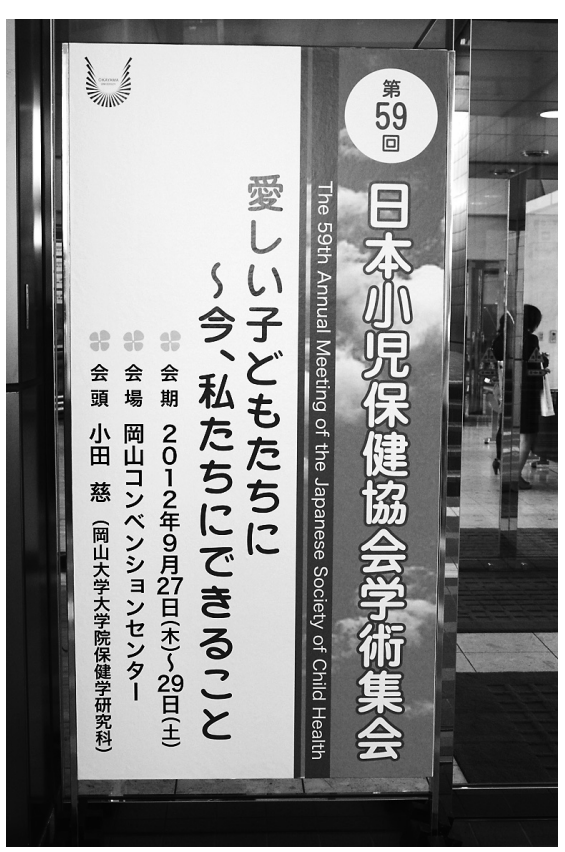




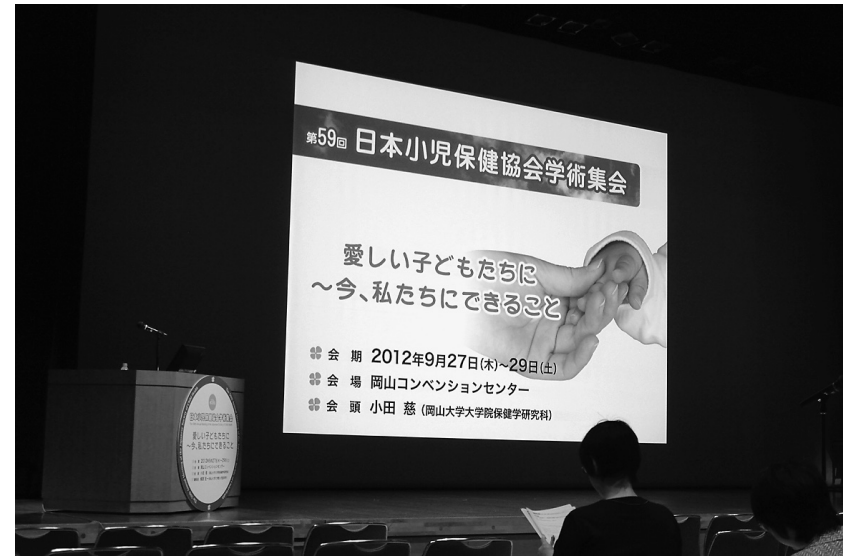

Service 交換留学生としての米国での高校生活体験か ら得た人生観から芽生えた国際貢献への気持ち, そし て, その後の世界各地での紛争の実態, そして平和の 大切さが, 自らの経験の中から伝えられ, 参加者の心 に深い感銘を与える講演となりました。

永く我が国に扮ける, 小児保健の実践と学術的リー ダーであった, 平山宗宏東京大学名誉教授による基調 講演「わが国の小児保健 百年の歩み一戦後50年で乳 児死亡率を世界最低にできた背景を考える一」では, 第 2 次世界大戦後, 20 世紀後半の我が国における小児 保健のレベルの目覚ましい向上とその背景が述べられ ました。平山先生をはじめとする先駆者の方々の想い やご努力を, 子どもたちの幸福のために, 今後, 現場 で小児保健に携わる人々は継続し, 引き継いでほしい というメッセージが込められていました.特別講演は, 小谷信行先生（松山赤十字病院副院長）による「地方 都市に㧍ける成育医療の試み〜多職種のメンバーの 協働の大切さ」, 谷池雅子先生 (大阪大学・金沢大学 · 浜松医科大学連合小児発達学研究科教授）による「科 学的視点をもって発達障害児を支援する」, 清野佳紀先 生（大阪厚生年金病院名誉院長／岡山大学名誉教授） による「医療現場におけるワークライフバランスの重 要性」, 森島恒雄先生 (岡山大学大学院医歯薬学総合研 究科小児医科学教授）による「院内感染で重要な小児 感染症」の何れも, 現在の小児医療・保健・福祉にお いて重要なテーマを取り上げた 4 講演が行われまし た. 更に教育講演として「子どもと家族を支える小児 保健サービス」,「こどもが突然倒れた! 救急車が到着 する前に何ができるか?」「背の低いこどもの見方」 「エビデンスのための統計学の基礎」「「グラウンデッ
ド・セオリー・アプローチ入門」の 5 講演, 指定講演 として「山梨県における小児救急体制『山梨システム』 の構築」が行われました。

シンポジウムでは，「ふだんのかかわりから始める 発達支援〜多職種が連携した子育て支援の輪の中 で〜」，「小児がん患者と家族および，子育て世代のが 几患者とその家族の支援」，「性同一障害診療の実際と 子どもに関する課題」，「こどものころから大切にした い, 歯, 目, 耳〜豊かな老後のために」,「ワクチンで 防ぐこどもの病気」の 5 つのテーマが取り上げられ， いずれの会場においても，シンポジストの方々の心の こもった講演，それに引き続く熱心なデイスカッショ ンが続きました。

一般演題は236題の応募があり, 全演題の発表が口演 で行われました，日頃の小児保健活動の実践，あるい は研究成果の発表が続き, 各会場で, 明日に続く質疑 応答が行われました。

今回の学術集会には, 全国から，1,000人を超える, 医師, 歯科医師, 看護師, 保健師, 養護教諭など教育 関係者，保育園・幼稚園関係者，行政関係者など多く の職種の方々のご参加がありました。心から御礼を申 し上げます。

また，開催にあたり，学術ランチ企画をはじめ，多 くの企業のご支援を受けました。最後になりましたが, プログラム選定委員を務めていただたた諸先生，学会 運営に携わっていただいた, 岡山大学医学部保健学科 学生, 大学院保健学研究科教員, 岡山大学小児科久夕 ッフの皆様, 特に学術集会事務局長を務めていただい た, 岡山大学大学院医歯薬学総合研究科小児医科学 塚原宏一准教授に, 厚く御礼申し上げます。

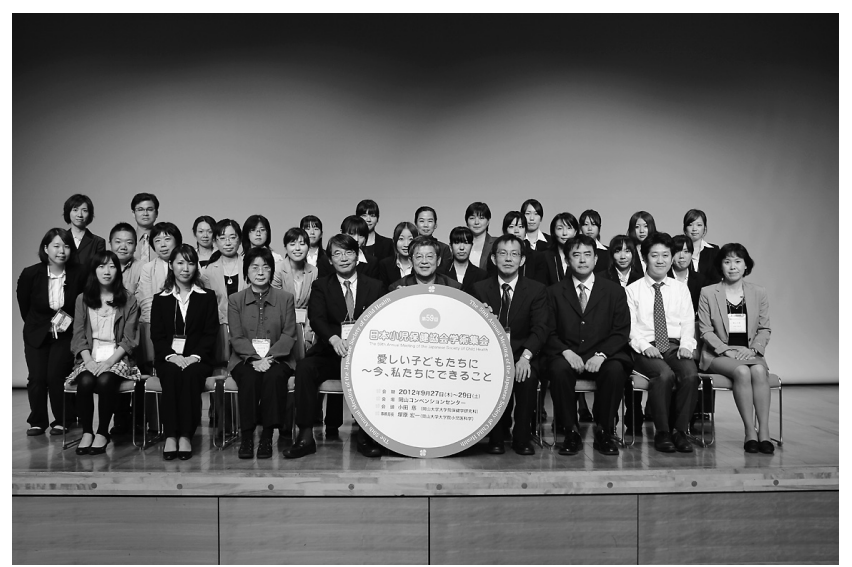

